Article

\title{
Chemosensory Gene Families in the Oligophagous Pear Pest Cacopsylla chinensis (Hemiptera: Psyllidae)
}

\author{
Ji-Wei Xu ${ }^{1}$, Xiu-Yun Zhu ${ }^{1}$, Qiu-Jie Chao ${ }^{1}$, Yong-Jie Zhang ${ }^{1}$, Yu-Xia Yang ${ }^{1}$, Ran-Ran Wang ${ }^{1}$, \\ Yu Zhang ${ }^{1}$, Meng-Zhen Xie ${ }^{1}$, Ya-Ting Ge ${ }^{1}$, Xin-Lai Wu ${ }^{1}$, Fan Zhang ${ }^{2}$, Ya-Nan Zhang ${ }^{1, *, t}$, \\ Lei $\mathrm{Ji}^{1, *}$ and $\mathrm{Lu} \mathrm{Xu}{ }^{3, *}$ \\ 1 College of Life Sciences, Huaibei Normal University, Huaibei 235000, China; jwxu32@163.com (J.-W.X.); \\ xyzhuhbnu@163.com (X.-Y.Z.); xuetao_26@163.com (Q.-J.C.); 15556116800@163.com (Y.-J.Z.); \\ yxyang0207@163.com (Y.-X.Y.); 18110329851@163.com (R.-R.W.); zzyy981012@163.com (Y.Z.); \\ a2574138112@163.com (M.-Z.X.); 13030605380@163.com (Y.-T.G.); wxlzy0822@163.com (X.-L.W.) \\ 2 Key Laboratory of Animal Resistance Research, College of Life Science, Shandong Normal University, \\ Jinan 250000, China; zhangfan@sdnu.edu.cn \\ 3 Key Lab of Food Quality and Safety of Jiangsu Province-State Key Laboratory Breeding Base, Institute of \\ Plant Protection, Jiangsu Academy of Agricultural Sciences, Nanjing 210014, China \\ * Correspondence: ynzhang_insect@163.com (Y.-N.Z.); 626j1@163.com (L.J.); xulupesticide@163.com (L.X.) \\ + First corresponding author.
}

Received: 26 April 2019; Accepted: 12 June 2019; Published: 17 June 2019

\begin{abstract}
Chemosensory systems play an important role in insect behavior, and some key associated genes have potential as novel targets for pest control. Cacopsylla chinensis is an oligophagous pest and has become one of the main pests of pear trees, but little is known about the molecular-level means by which it locates its hosts. In this study, we assembled the head transcriptome of $C$. chinensis using Illumina sequencing, and 63,052 Unigenes were identified. A total of 36 candidate chemosensory genes were identified, including five different families: 12 odorant binding proteins (OBPs), 11 chemosensory proteins (CSPs), 7 odorant receptors (ORs), 4 ionotropic receptors (IRs), and 2 gustatory receptors (GRs). The number of chemosensory gene families is consistent with that found in other Hemipteran species, indicating that our approach successfully obtained the chemosensory genes of $C$. chinensis. The tissue expression of all genes using quantitative real-time PCR (qRT-PCR) found that some genes displayed male head, female head, or nymph-biased specific/expression. Our results enrich the gene inventory of $C$. chinensis and provide valuable resources for the analysis of the functions of some key genes. This will help in developing molecular targets for disrupting feeding behavior in C. chinensis.
\end{abstract}

Keywords: Cacopsylla chinensis; oligophagous pest; chemosensory genes; transcriptome analysis; tissue expression

\section{Introduction}

Insect chemosensory systems interpret and react to various environmental chemical factors, and impact various life cycle processes, including feeding, predator avoidance, and reproductive behavior [1,2]. Recognition of these behaviors frequently involves a series of genes, including those that encode odorant binding proteins (OBPs), chemosensory proteins (CSPs), odorant receptors (ORs), ionotropic receptors (IRs), and gustatory receptors (GRs) [3-5]. These proteins participate in extremely complex biochemical reactions in various tissues to ensure accurate delivery of chemical signals [6].

OBPs and CSPs are two families of integral membrane proteins located on the dendrites of olfactory receptor neurons (ORNs), and are abundant in the lymph antennae [7]. These can capture and 
bind environmental chemical signals [8,9], which are then transferred to ORs or IRs. The first insect OBPs and CSPs were identified in Antheraea polyphemus and Drosophila melanogaster, respectively [10,11]. OBPs are small and water-soluble extracellular proteins predominantly expressed in the antennae and are used to transmit hydrophobic odor molecules to ORs [12,13]. CSPs are smaller than OBPs and characterized by four conserved cysteines, and exist in almost all olfactory organs and non-olfactory organs, indicating their functional diversity [14].

Chemosensory receptors often contain ORs, IRs, and GRs. ORs are particularly vital in the process of insect and host odor recognition [15-17] and have seven transmembrane domain-like G protein-coupled receptors [18]. Two types of ORs are expressed in insect olfactory sensory neurons (OSNs), including conventional ORs and an odorant co-receptor (Orco; formerly called OR83b) that lacks odor sensitivity $[19,20]$. ORs can combine with most environmental odorants encoded by a trans-fiber pattern to activate OSNs [21,22]. A specialized OR of D. melanogaster is activated by specific odors that trigger an innate response [23]. IRs used to sense environmental chemicals belong to an evolutionarily older class of receptors, including a newly-discovered protein family operating as conserved ligand-gated ion channel receptors referred to as ionotropic glutamate receptors (iGluRs) [24-26], as well as divergent IRs [27]. There are likewise various antennal IRs [28,29], indicating that IR families play different roles in the process of insects' recognition of external information. GRs can recognize various materials such as salts, $\mathrm{CO}_{2}$, sugars, and organic compounds [30], and are involved in the feeding activities of insects [31-33]. In recent years, various chemosensory genes have been discovered in a number of insect species, including Adelphocoris suturalis [34], the sweet potato weevil Cylas formicarius [35], Bemisia tabaci [36], and D. melanogaster [37], using RNA sequencing (RNA-seq) technology as an effective method to identify such genes.

Cacopsylla chinensis (Yang \& Li 1981), belonging to the Psyllidae family among the Homoptera, grows in temperate and subtropical regions of the world [38], including China and Japan, and has become one of the main pests of pear trees in China [39]. C. chinensis is an oligophagous pest that can damage buds and fresh leaves and infect healthy pear trees with decaying disease [40]. The nymphs of C. chinensis also secrete a mucus that supports various bacterial growth, affecting pear quality [41]. No molecular-mediated chemosensory behaviors in C. chinensis have yet been defined. Targeting pests using chemosensory disruptors can interfere with the insects' ability to find hosts, feed, and reproduce, and a thorough definition of chemosensation in C. chinensis could suggest novel strategies for controlling this pest. In this study, we aim at identifying such potential target genes related to insect chemosensation. We first conducted head transcriptome analysis of $C$. chinensis and then further analyzed the phylogenetic trees and examined tissue expression of the chemosensory genes. It provided the basis for proteomics analysis [42] and searching the potential control strategies [43].

\section{Material and Methods}

\subsection{Tissue Sample Collection}

The morphological picture of $C$. chinensis is shown in Figure 1. Three hundred C. chinensis (100 males, 100 females, and 100 nymphs) were collected from Dangshan (34²7'42.62” N, 116 31'40.72" E), Suzhou, China. The 300 heads were dissected out under a stereomicroscope with a sterile scalpel and immediately mixed into liquid nitrogen and sent to Genepioneer Biotech Corporation (Nanjing, China) for RNA-seq. For quantitative real-time PCR (qRT-PCR) analysis, we separately collected 60 males, 60 females, and 60 nymphs divided into heads only or bodies only. They were separately named as $\mathrm{MH}$, male head; MB, male body; FH, female head; FB, female body; NH, nymph head and NB, nymph body and placed in nuclease-free centrifuge tubes as one replicate. Each replicate was repeated three times. All samples were preserved in liquid nitrogen until RNA extraction. 


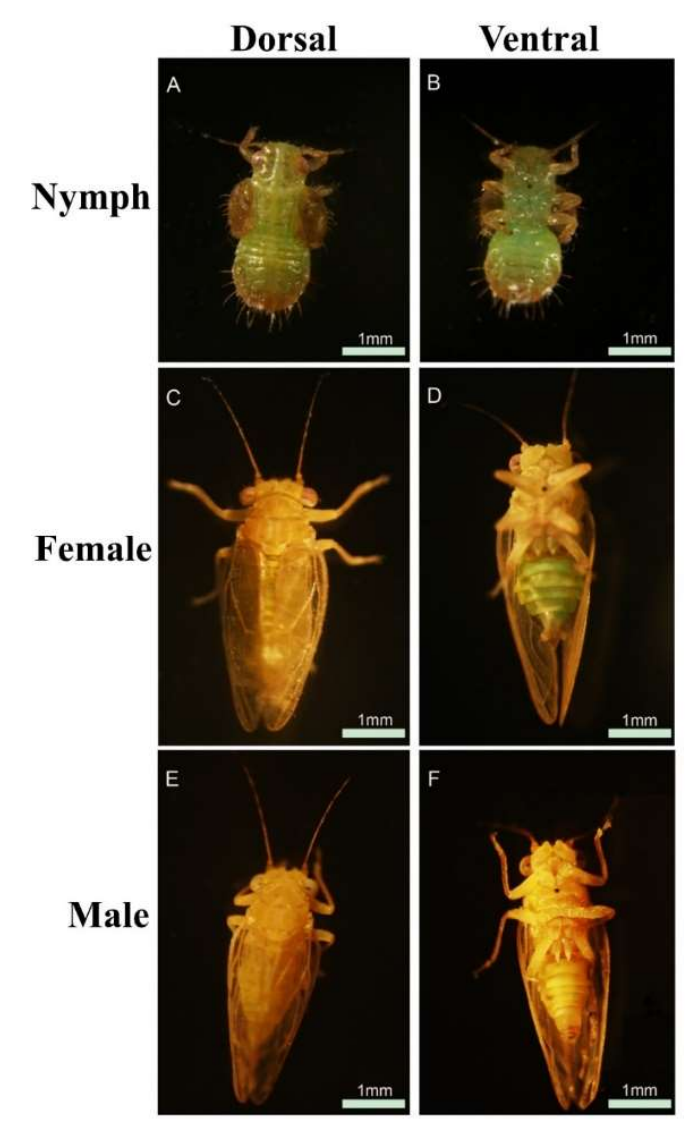

Figure 1. Photographs of Cacopsylla chinensis.

\subsection{Total RNA Extraction and cDNA Synthesis}

We used the MiniBEST Universal RNA Extraction Kit (TaKaRa, Dalian, China) to extract total RNA following the manufacturer's instructions. RNA quality and concentration were analyzed using an ultramicro-spectrophotometer (MD2000D, Biofuture, UK). The RNA was stored at $-80^{\circ} \mathrm{C}$ prior to use. Single-stranded cDNA templates were synthesized using $1 \mu \mathrm{g}$ total RNA from various tissue samples, using primers from the PrimeScript ${ }^{\mathrm{TM}}$ RT Master Mix (TaKaRa, Dalian, China).

\subsection{Library Preparation for Transcriptome Sequencing}

For sequencing, total RNA was extracted using the TRIzol ${ }^{\circledR}$ reagent (Tiangen Biotech, Beijing, China) $[44,45]$ and checked for quality. The mRNA was enriched using magnetic beads, then fragmented randomly by adding fragmentation buffer. First-strand cDNA was synthesized using mRNA templates and a random hexamer and the second cDNA chain was synthesized by adding buffers, dNTPs, RNAse $\mathrm{H}$, and DNA polymerase I. The cDNA was then purified using AMPure XP beads (Beckman Coulter, Beverly, MA, USA). Purified double-strand cDNA was used for end repair, adding poly-A tails and adapters [46]. Finally, cDNA libraries were obtained by PCR. Library concentration and insert size were detected using a Qubit ${ }^{\circledR}$ 2.0 Fluorometer (Life Technologies, Grand Island, NY, USA) and an Agilent Bioanalyzer 2100 system. Quantitative qRT-PCR was used to accurately quantify the effective concentration of the library to ensure its quality. Finally, the cDNA library was sequenced using an Illumina Hiseq 4000 platform with the paired-end (PE) and the sequencing read length was PE150bp.

\subsection{De Novo Assembly and Unigene Annotation}

After using sequencing by synthesis (SBS) technology, raw reads were cleaned by removing adaptor reads, ambiguous reads (' $\mathrm{N}^{\prime}>10 \%$ ), and low-quality reads (that is, where more than $50 \%$ of bases in a read had a quality value $\mathrm{Q} \leq 5$ ) using Perl script. Clean reads were then de novo assembled 
using the Trinity program v2.4.0 (http://trinityrnaseq.sourceforge.net/) with default parameters [47], and the minimal contig length is $301 \mathrm{bp}$. The reads of $C$. chinensis have been deposited (accession number: SRA9127897). BLAST (http://blast.ncbi.nlm.nih.gov/Blast.cgi) was used to compare Unigene sequences with databases including $\mathrm{Nr}$ (non-redundant database) [48], Swiss-Prot [49], KEGG (Kyoto Encyclopedia of Genes and Genomes) [50], KOG (EuKaryotic Orthologous Groups) [51], and COG (Clusters of Orthologous Groups) [52] to obtain amino acid sequences of Unigene genes. Then, HMMER [53] software was used to compare with the Pfam [54] database (including chemosensory proteins families in different insects) to obtain the annotation information of Unigene.

\subsection{Phylogenetic Analysis}

Phylogenetic trees were constructed using amino acid sequences of candidate genes including CchiOBPs, CchiCSPs, CchiORs, CchiIRs, and CchiGRs of C. chinensis (Table S1), and the signal peptide sequences of OBPs and CSPs were predicted by SignalP 4.1 server [55] with default parameters and then removed. The sequences were aligned by using ClustalX 2.0 (University College Dublin, Dublin, Ireland), and phylogenetic trees were constructed using PhyML [56] based on an LG substitution model [57] with nearest-neighbor interchange (NNI). Branch support was estimated using a Bayesian-like transformation of the aLRT (aBayes) method. Dendrograms were edited using FigTree software (http://tree.bio.ed.ac.uk/software/figtree/).

\subsection{Quantitative Real-Time PCR}

We used qRT-PCR to determine the relative expression levels of chemosensory genes in different tissues (MH, MB, FH, FB, NH, and NB). The experiment was performed in a LightCycler ${ }^{\circledR} 96$ (Roche Diagnostics Gmbh, Basel, Switzerland) according to the minimum information for publication of qRT-PCR experiments [58], using a total mixture of $10 \mu \mathrm{L}$ with $5 \mu \mathrm{L}$ 2X SYBR Green PCR Master Mix (YIFEIXUE BIO TECH, Nanjing, China), $0.2 \mu \mathrm{L}$ paired primers designed using Beacon Designer 7.9 (PREMIER Biosoft International, CA, USA) (Table S2) to check for the absence of primer-dimer peaks, 3.6 $\mu \mathrm{L}$ nuclease-free water, and $1 \mu \mathrm{L}$ cDNA. The amplification step was executed using a degeneration step at $95^{\circ} \mathrm{C}$ for $10 \mathrm{~min}$, followed by 40 cycles of $95^{\circ} \mathrm{C}$ for $15 \mathrm{~s}$ and $60^{\circ} \mathrm{C}$ for $60 \mathrm{~s}$. The melting curve detected a single primer-specific peak, using $93^{\circ} \mathrm{C}$ for $30 \mathrm{~s}$ and $60^{\circ} \mathrm{C}$ for $45 \mathrm{~s}$. A negative control was created using distilled water instead of cDNA template for each test run.

CchiGAPDH (glyceraldehyde-3-phosphate dehydrogenase) and CchiEF (elongation factor 1-alpha) (Genbank numbers CchiGAPDH: MK940861, CchiEF: MK940862) were used as internal reference genes to calculate the expression of different genes in different tissues. This was carried out using the Microsoft Excel-based software Visual Basic using the Q-Gene method [59]. For six samples, each biological sample was repeated three times in a LightCycler ${ }^{\circledR} 96$ multiwell plate.

\subsection{Statistical Analysis}

Relative expressions of chemosensory genes (mean \pm standard error) were compared using one-way ANOVA in SPSS 21.0 software (SPSS Inc., Chicago, IL, USA), according to the least significance difference (LSD). Differences were regarded as significant at $p<0.05$. The GraphPad ${ }^{\mathrm{TM}}$ Prism 7.0 software (GraphPad Software Inc., San Diego, CA, USA) was used to perform the figures [60]. 


\section{Results}

\subsection{Transcriptome Sequencing and Assembly}

We generated a total of 32,879,148 clean reads from a cDNA library using transcriptome sequencing (Table 1). The percentage of reads with Q20 and Q30 quality scores was 99\% and 91.25\%, respectively. De novo assembly yielded 63,052 Unigenes of high assembly integrity with a mean length of 64,826 bp and a maximum length of 20,509 bp.

Table 1. Summary of Cacopsylla chinensis transcriptome assembly.

\begin{tabular}{cc}
\hline Statistics Project & Number \\
\hline Total clean reads & $32,879,148$ \\
GC percentage & $34.11 \%$ \\
Q20 percentage & $99 \%$ \\
Total Unigene nucleotides & $40,874,177$ \\
Total Unigenes & 63,052 \\
N50 of Unigenes (nt) & 702 \\
Min length of Unigenes (nt) & 201 \\
Mean length of Unigenes (nt) & 648.26 \\
Max length of Unigenes (nt) & 20,509 \\
Unigenes with homolog in NR & 22,392 \\
\hline
\end{tabular}

\subsection{Homology Analysis}

Blastx homology searches of all 63,052 Unigenes showed that 22,963 (36.41\%) had homologous genes in the non-redundant $(\mathrm{Nr})$ protein database with a cut-off E-value of $10^{-5}$. The best match percentage (58\%) was with Diaphorina citri sequences, followed by sequences from Acyrthosiphon pisum (3\%), Zootermopsis nevadensis (4\%), Tribolium castaneum (3\%), and others (32\%) (Figure 2).

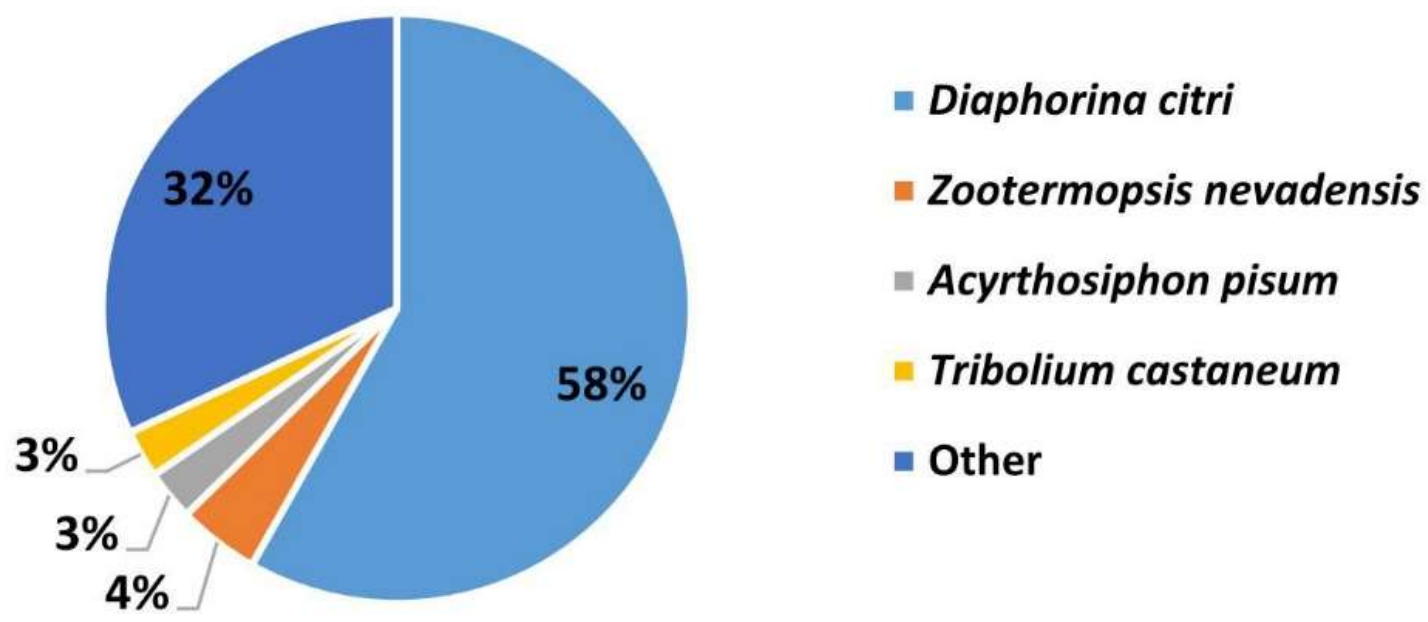

Figure 2. Percentage of homologous hits of the C. chinensis transcripts to other species. Blastx searched the $C$. chinensis transcripts against the non-redundancy protein database with a cut-off E-value of $10^{-5}$. Species that have more than $3 \%$ matching hits to the C. chinensis transcripts are shown. 


\subsection{Non-Receptor Chemosensory Gene Families}

Odorant Binding Proteins (OBPs)

A total of twelve putative OBP genes were identified and named as CchiOBP1-12. The phylogenetic trees of the CchiOBPs were constructed using three Hemipteran species, including D. citri, Aphis gossypii, Sogatella furcifera, and Diptera Drosophila melanogaster (Figure 3). The results show that CchiOBPs had several putative one-to-one orthologous relationships with these species, and only CchiOBP1 belongs to the Plus-C subgroup; the other CchiOBPs were clustered in the Classic subgroup. Among the CchiOBP genes, six CchiOBPs (CchiOBP1, CchiOBP4, CchiOBP5, CchiOBP9, CchiOBP10, and CchiOBP12) had full open reading frames (ORFs) to encode 104 to 238 amino acids and had signal peptides at the N-terminus (Table 2). The expression profiles of all CchiOBPs showed that all CchiOBPs were highly expressed in the heads (Figure 4). Among the CchiOBPs, five CchiOBPs (CchiOBP1, 3-6) were more highly expressed in female heads $(\mathrm{FH})$ than in male heads $(\mathrm{MH})(p<0.05)$. CchiOBP12 was highly expressed in the heads of both male and female adults. Three CchiOBPs (CchiOBP7, CchiOBP10, and CchiOBP11) were highly expressed in male heads, with CchiOBP7 exhibiting the highest expression level. Additionally, two CchiOBPs (CchiOBP2 and 9) exhibited significantly higher expression in nymph heads $(\mathrm{NH})$ than other tissues, and CchiOBP8 showed specific expression in nymphs.

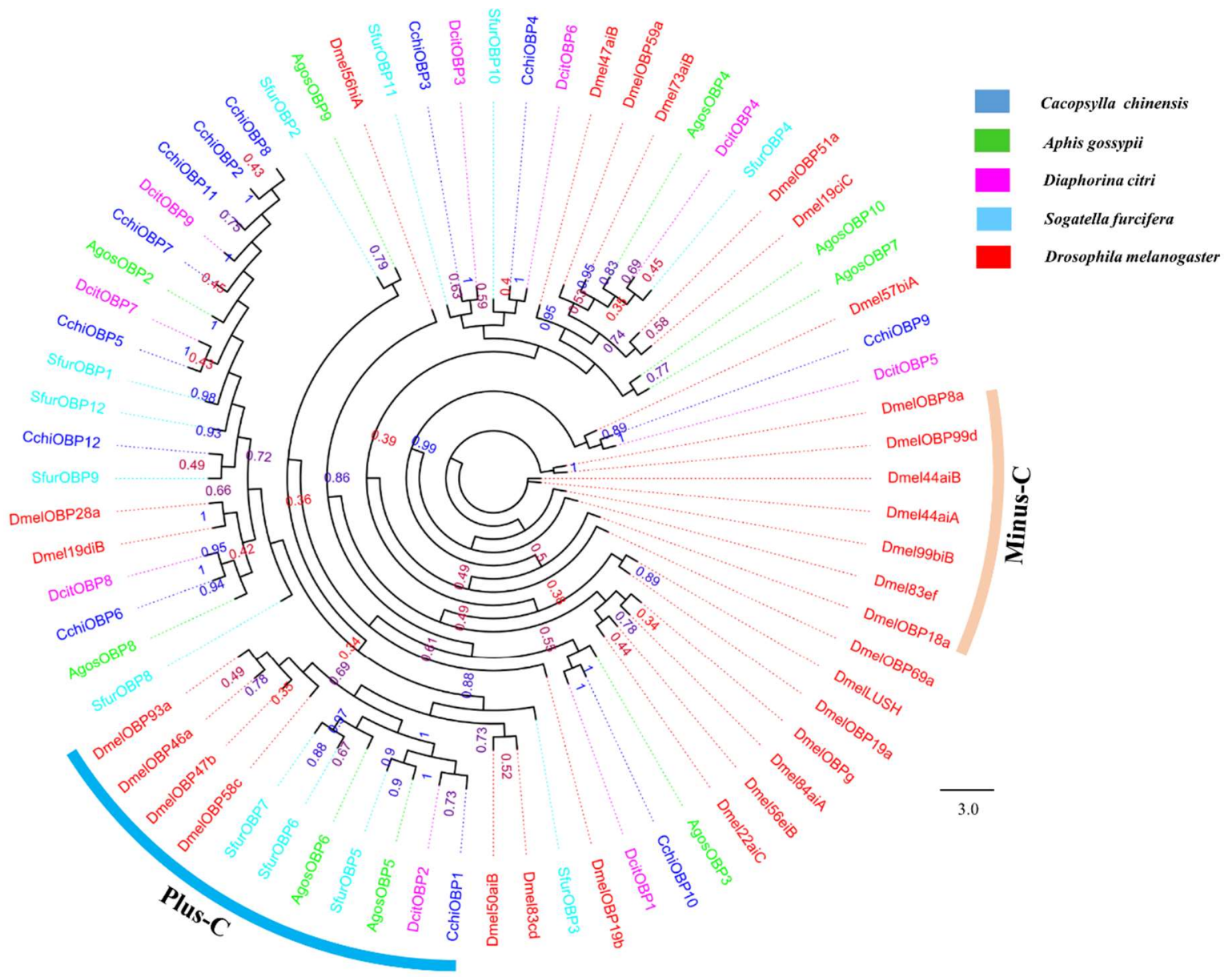

Figure 3. Phylogenetic tree of insect odorant binding proteins (OBPs). The C. chinensis translated genes are shown in blue. Abbreviations of other insects are as follows: Aphis gossypii, Diaphorina citri, Sogatella furcifera, Drosophila melanogaster. This tree was constructed using PhyML based on the alignment results of ClustalX2.0. 
Table 2. The Blastx match of C. chinensis odorant binding protein (OBP) genes, chemosensory protein (CSP) genes, odorant receptor (OR) genes, ionotropic receptor (IR) genes, and gustatory receptor (GR) genes.

\begin{tabular}{|c|c|c|c|c|c|c|c|c|}
\hline \multirow{2}{*}{$\begin{array}{l}\text { Gene } \\
\text { Name }\end{array}$} & \multirow{2}{*}{$\begin{array}{l}\text { ORF } \\
\text { (aa) }\end{array}$} & \multirow{2}{*}{$\begin{array}{l}\text { Signal } \\
\text { Peptide }\end{array}$} & \multirow{2}{*}{$\begin{array}{c}\text { Complete } \\
\text { ORF }\end{array}$} & \multicolumn{5}{|c|}{ Best Blastx Match } \\
\hline & & & & Name & Acc. No. & Species & E-value & Identity (\%) \\
\hline \multicolumn{9}{|c|}{ Odorant Binding Protein (OBP) } \\
\hline OBP1 & 238 & $1-24$ & $\mathrm{Y}$ & odorant-binding protein 5 & AHB59658.1 & Sogatella furcifera & $8.00 \times 10^{-34}$ & 36 \\
\hline ОВР2 & 105 & - & $\mathrm{N}$ & odorant-binding protein 1 & ARR95844.1 & Diaphorina citri & $4.00 \times 10^{-26}$ & 52 \\
\hline ОВР3 & 65 & - & $\mathrm{N}$ & general OBP 83a-like & XP_008470659.1 & Diaphorina citri & $1.00 \times 10^{-226}$ & 65 \\
\hline OBP4 & 122 & $1-25$ & $\mathrm{Y}$ & odorant-binding protein 5 & ATO59032.1 & Schistocerca gregaria & $8.00 \times 10^{-13}$ & 37 \\
\hline OBP5 & 145 & $1-21$ & $\mathrm{Y}$ & odorant-binding protein 1 & ARR95844.1 & Diaphorina citri & $1.00 \times 10^{-27}$ & 38 \\
\hline OBP6 & 75 & - & $\mathrm{N}$ & odorant-binding protein 8 & AMD82868.1 & Bemisia tabaci & $8.00 \times 10^{-18}$ & 56 \\
\hline OBP7 & 61 & - & $\mathrm{N}$ & odorant-binding protein 1 & ARR95844.1 & Diaphorina citri & $2.00 \times 10^{-26}$ & 84 \\
\hline ОВР8 & 82 & - & $\mathrm{N}$ & odorant-binding protein 1 & ARR95844.1 & Diaphorina citri & $7.00 \times 10^{-19}$ & 54 \\
\hline ОВР9 & 135 & $1-21$ & Y & general OBP $57 \mathrm{c}$ isoform $\mathrm{X} 2$ & XP_021924930.1 & Zootermopsis nevadensis & $5.00 \times 10^{-25}$ & 39 \\
\hline OBP10 & 135 & $\mathrm{~N}$ & $\mathrm{Y}$ & odorant-binding protein 3 & AGE97633.1 & Aphis gossypii & $2.00 \times 10^{-13}$ & 32 \\
\hline OBP11 & 86 & - & $\mathrm{N}$ & odorant-binding protein 1 & ARR95844.1 & Diaphorina citri & $6.00 \times 10^{-25}$ & 54 \\
\hline ОВР12 & 104 & $1-24$ & $\mathrm{Y}$ & putative odorant-binding protein A10 & XP_008473937.1 & Diaphorina citri & $5.00 \times 10^{-46}$ & 55 \\
\hline \multicolumn{9}{|c|}{ Chemosensory Protein (CSP) } \\
\hline CSP1 & 80 & - & $\mathrm{N}$ & chemosensory protein & AJP61962.1 & Phenacoccus solenopsis & $1.00 \times 10^{-16}$ & 39 \\
\hline CSP2 & 104 & $1-24$ & $\mathrm{Y}$ & chemosensory protein & AVM86436.1 & Corythucha ciliata & $3.00 \times 10^{-16}$ & 37 \\
\hline CSP3 & 161 & $1-16$ & $\mathrm{Y}$ & ejaculatory bulb-specific protein 3-like & XP_008478860.1 & Diaphorina citri & $5.00 \times 10^{-52}$ & 66 \\
\hline CSP4 & 103 & $1-19$ & $\mathrm{Y}$ & ejaculatory bulb-specific protein 3-like & XP_008471453.1 & Diaphorina citri & $2.00 \times 10^{-60}$ & 75 \\
\hline CSP5 & 91 & - & $\mathrm{N}$ & chemosensory protein 1 & ARR95843.1 & Diaphorina citri & $1.00 \times 10^{-38}$ & 74 \\
\hline CSP6 & 105 & - & $\mathrm{N}$ & ejaculatory bulb-specific protein 3-like & P_008478140.1 & Diaphorina citri & $1.00 \times 10^{-64}$ & 89 \\
\hline CSP7 & 121 & $1-19$ & Y & ejaculatory bulb-specific protein 3-like & XP_008473947.1 & Diaphorina citri & $3.00 \times 10^{-52}$ & 79 \\
\hline CSP8 & 141 & $1-21$ & $\mathrm{Y}$ & ejaculatory bulb-specific protein 3-like & XP_018916603.1 & Bemisia tabaci & $1.00 \times 10^{-38}$ & 79 \\
\hline CSP9 & 91 & - & $\mathrm{N}$ & ejaculatory bulb-specific protein 3-like & XP_017300318.1 & Diaphorina citri & $4.00 \times 10^{-59}$ & 81 \\
\hline CSP10 & 132 & $1-19$ & Y & chemosensory protein & ĀJP61957.1 & Phenacoccus solenopsis & $1.00 \times 10^{-22}$ & 41 \\
\hline CSP11 & 103 & $1-19$ & $\mathrm{Y}$ & ejaculatory bulb-specific protein 3-like & P_008478860.1 & Diaphorina citri & $2.00 \times 10^{-74}$ & 89 \\
\hline \multicolumn{9}{|c|}{ Odorant receptors (OR) } \\
\hline OR1 & 242 & - & $\mathrm{N}$ & odorant receptor $82 \mathrm{a}$ & XP_008477835.1 & Diaphorina citri & $3.00 \times 10^{-25}$ & 46 \\
\hline OR2 & 96 & - & $\mathrm{N}$ & odorant receptor 83b & ADB82908.1 & Loxostege sticticalis & $8.00 \times 10^{-50}$ & 83 \\
\hline OR3 & 150 & - & $\mathrm{N}$ & odorant receptor $85 \mathrm{c}$-like & XP_008476350.1 & Diaphorina citri & $3.00 \times 10^{-18}$ & 33 \\
\hline OR4 & 123 & - & $\mathrm{N}$ & odorant receptor 82a & XP_008477835.1 & Diaphorina citri & $1.00 \times 10^{-14}$ & 32 \\
\hline OR5 & 333 & - & $\mathrm{N}$ & odorant receptor 82a & XP_008477835.1 & Diaphorina citri & $4.00 \times 10^{-04}$ & 53 \\
\hline OR6 & 352 & - & $\mathrm{N}$ & odorant receptor $82 \mathrm{a}$ & XP_008477835.1 & Diaphorina citri & $1.00 \times 10^{-11}$ & 24 \\
\hline OR7 & 321 & - & $\mathrm{N}$ & odorant receptor $82 \mathrm{a}$ & XP_008477835.1 & Diaphorina citri & $6.00 \times 10^{-06}$ & 38 \\
\hline \multicolumn{9}{|c|}{ Ionotropic receptors (IR) } \\
\hline IR1 & 73 & - & $\mathrm{N}$ & ionotropic receptor 21a isoform X2 & XP_024936966.1 & Cephus cinctus & $4.00 \times 10^{-09}$ & 45 \\
\hline IR2 & 205 & - & $\mathrm{N}$ & ionotropic receptor & ĀUF73076.1 & Anoplophora chinensis & $7.00 \times 10^{-78}$ & 79 \\
\hline IR3 & 120 & - & $\mathrm{N}$ & ionotropic receptor 24 & ALD51351.1 & Locusta migratoria & $2.00 \times 10^{-22}$ & 50 \\
\hline IR4 & 145 & - & $\mathrm{N}$ & ionotropic receptor 6 & AVH87294.1 & Holotrichia parallela & $1.00 \times 10^{-36}$ & 59 \\
\hline \multicolumn{9}{|c|}{ Gustatory receptor (GR) } \\
\hline GR1 & 207 & - & $\mathrm{N}$ & GR for sugar taste 64 f-like & XP_008467720.2 & Diaphorina citri & $2.00 \times 10^{-84}$ & 78 \\
\hline GR2 & 200 & - & $\mathrm{N}$ & gustatory receptor & ABY40623.1 & Tribolium castaneum & $5.00 \times 10^{-41}$ & 45 \\
\hline
\end{tabular}



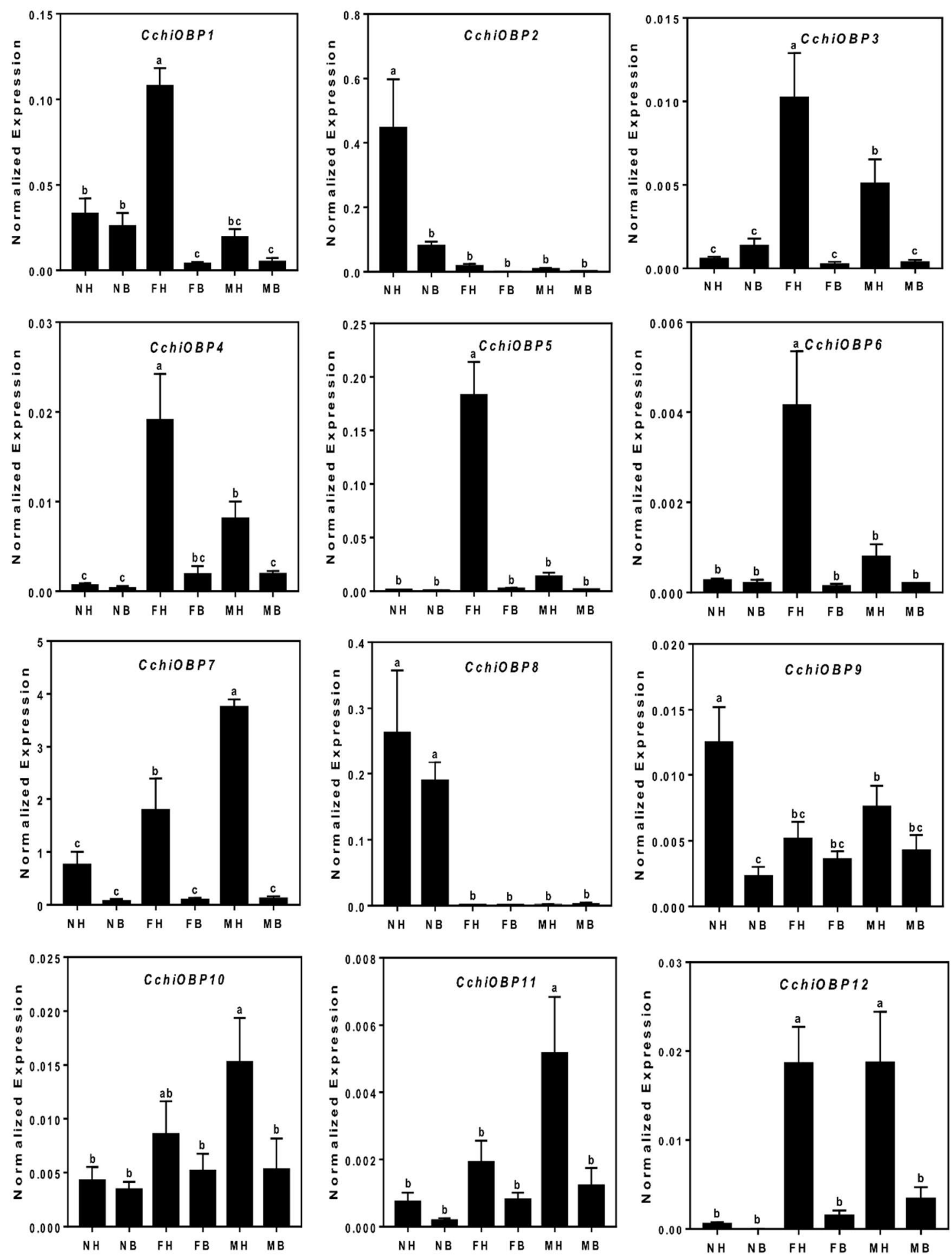

Figure 4. The tissue expression of $\mathrm{OBP}$ genes in $C$. chinensis. The different lowercase letters mean significance between tissues ( $p<0.05$, ANOVA, least significance difference (LSD)). NH, nymph head; $\mathrm{NB}$, nymph body; FH, female head; FB, female body; $\mathrm{MH}$, male head; $\mathrm{MB}$, male body. 


\subsection{Chemosensory Proteins (CSPs)}

In all, we identified eleven transcripts encoding putative CSPs in C. chinensis. Seven were full-length genes with predicted signal peptide sequences (Table 2) and had four conserved cysteines in corresponding positions. All CchiCSPs shared 37-89\% amino acid identity with other Hemipteran insects. The phylogenetic tree results indicate that all CchiCSPs were distributed on various branches, with one D. citri ortholog distribution on each branch (Figure 5). The qRT-PCR results of all CchiCSPS showed that CchiCSP1, CchiCSP3, and CchiCSP8 were highly or specifically expressed in nymph heads. CchiCSP2 had adult head-biased expression, but CchiCSP4 displayed adult body-specific expression. CchiCSP9 and CchiCSP10 were significantly highly expressed in male and female bodies, respectively (Figure 6).

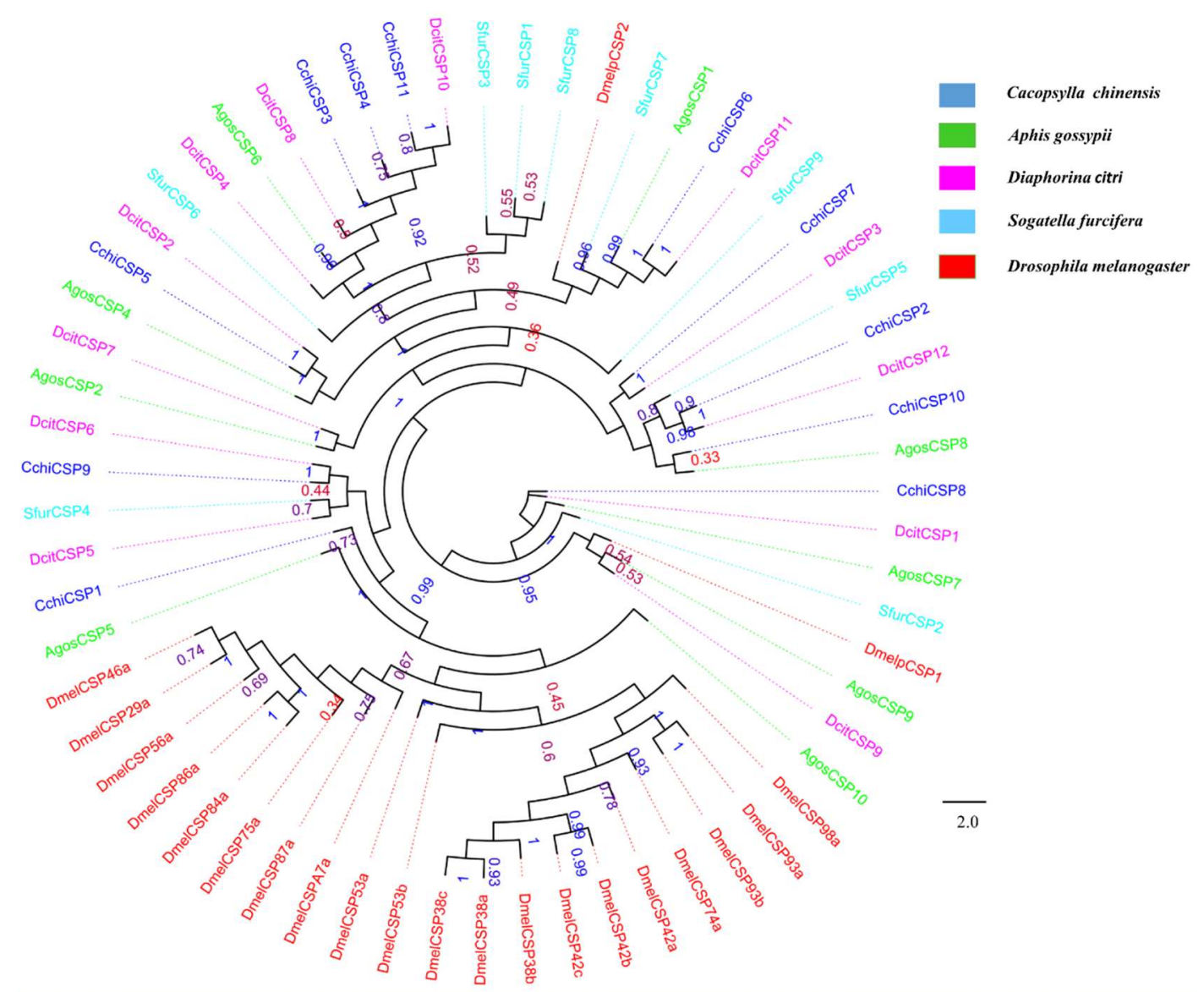

Figure 5. Phylogenetic tree of insect chemosensory proteins (CSPs). The C. chinensis translated genes are shown in blue. Other insects are as follows: Aphis gossypii, Diaphorina citri, Sogatella furcifera, Drosophila melanogaster. This tree was constructed using PhyML based on the alignment results of ClustalX2.0. 

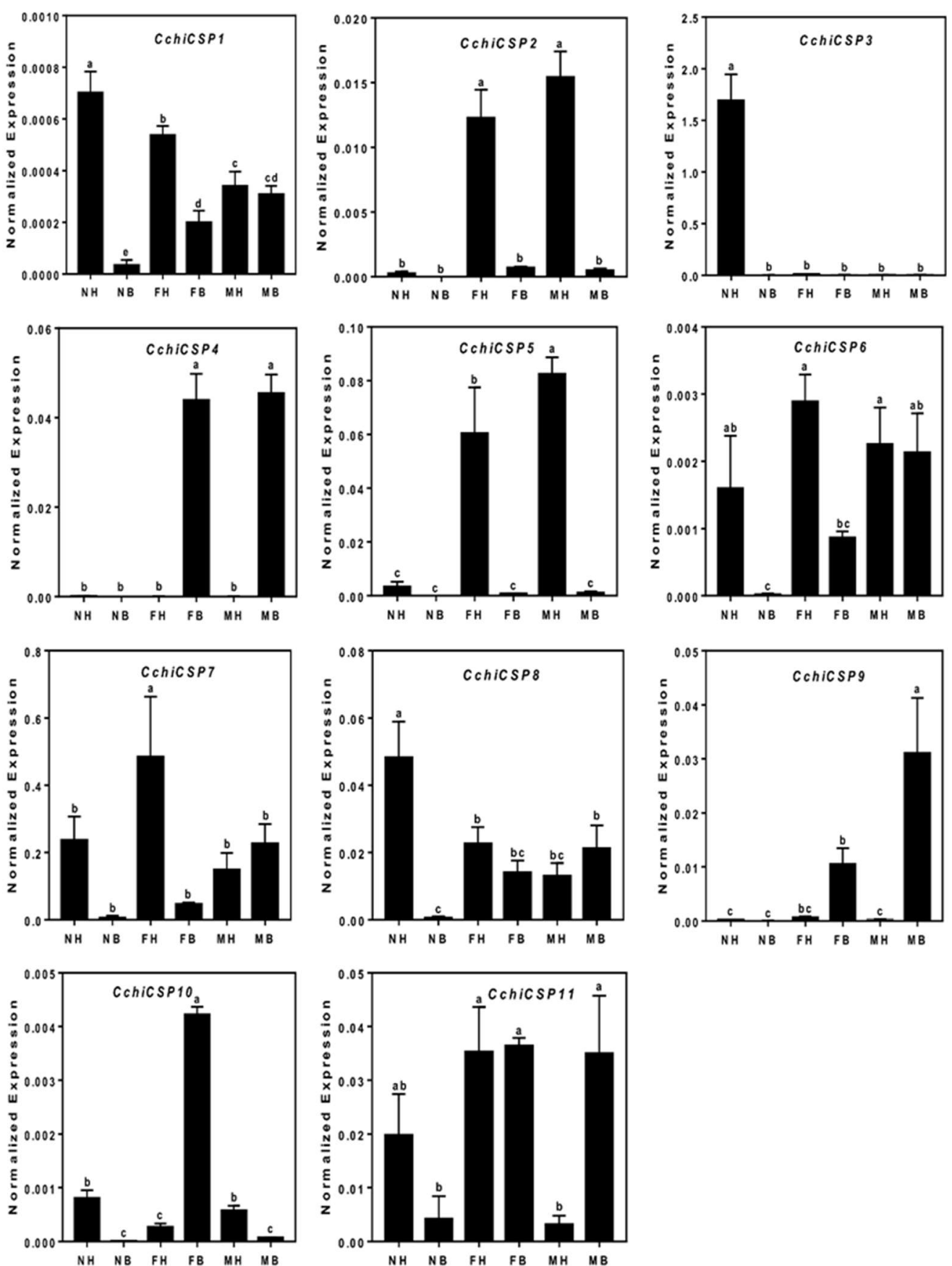

Figure 6. The tissue expression of CSP genes in C. chinensis. The different lowercase letters mean significance between tissues ( $p<0.05$, ANOVA, LSD). NH, nymph head; NB, nymph body; FH, female head; FB, female body; $\mathrm{MH}$, male head; $\mathrm{MB}$, male body.

\subsection{Chemosensory Receptor Gene Families}

Odorant receptors (ORs), ionotropic receptors (IRs), and gustatory receptors (GRs)

We identified 13 distinct Unigenes putatively as seven ORs, four IRs, and two GRs (Table 2). Phylogenetic trees for CchiORs (Figure 7), CchiIRs (Figure 8), and CchiGRs (Figure 9) were constructed using amino acid sequences from $C$. chinensis and other insects. We found that the CchiORs were highly homologous to $D$. citri, and CchiOR2 belonged to the Orco family that is widely expressed and highly conserved in insects. In the phylogenetic tree of CchilRs and CchiGRs, we found that all CchilRs belong to the antennal IRs, but CchiGRs were not clustered in the $\mathrm{CO}_{2}$ or sugar receptor 
families. Tissue expression analysis showed that almost all were more highly expressed in adults than in nymphs, although CchiOR6 was specifically expressed in the male bodies of nymphs (Figure 10). CchiOR1 and CchiOR2 were more highly expressed in adult heads compared to other tissues, and CchiOR3 and CchiOR4 were more expressed in male heads and bodies. Meanwhile, CchiOR5 was more abundant in nymph and female heads. CchiIR1 and CchiIR3 were more highly expressed in nymph bodies and female bodies, respectively, while CchiIR2 showed adult head-biased expression. However, both CchiGR1 and CchiGR2 were highly expressed in nymph heads (Figure 10).

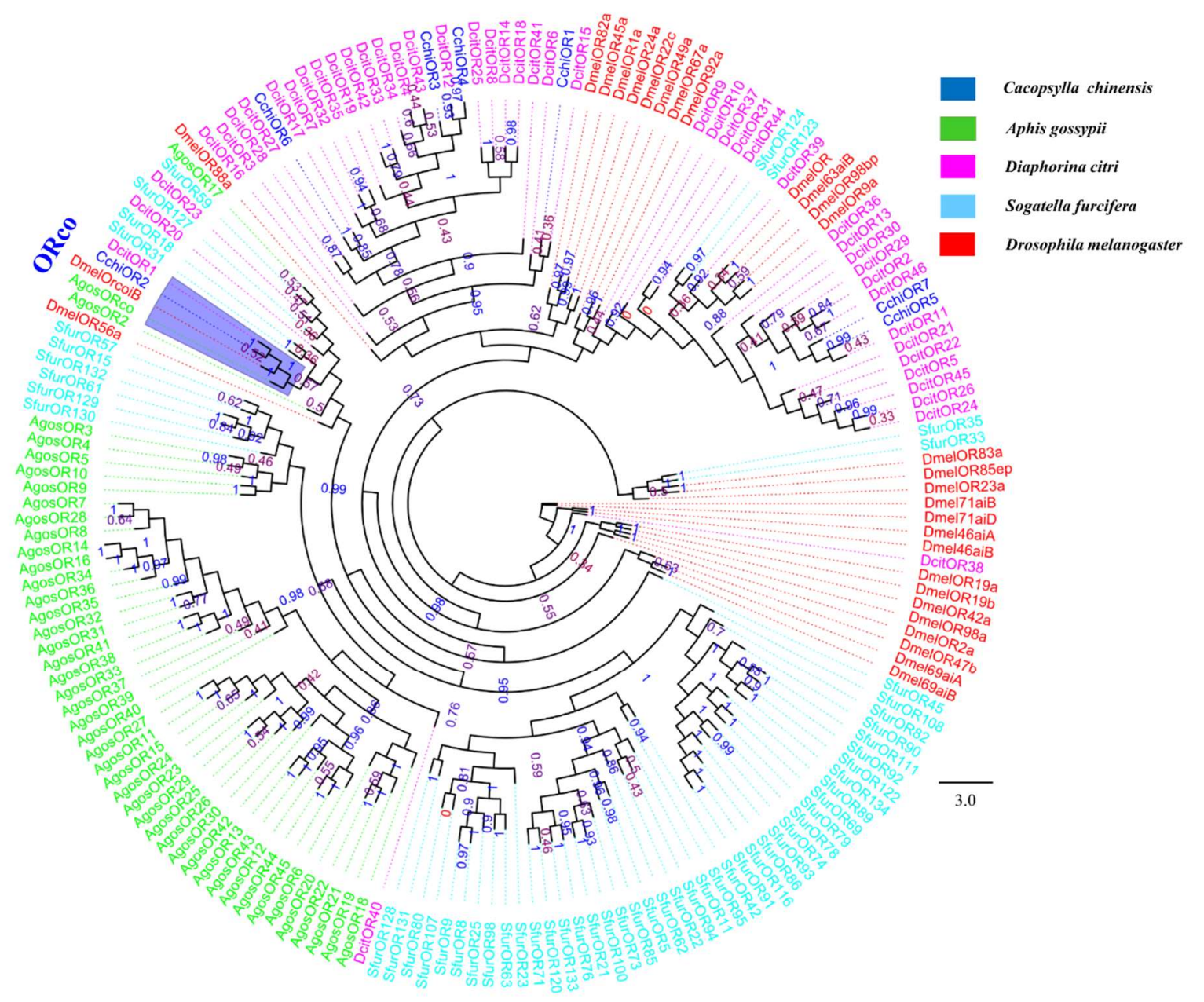

Figure 7. Phylogenetic tree of insect odorant receptors (ORs). The C. chinensis translated genes are shown in blue. Other insects are as follows: Aphis gossypii, Diaphorina citri, Sogatella furcifera, Drosophila melanogaster. Orco clade is marked in blue. This tree was constructed using PhyML based on the alignment results of ClustalX2.0. 


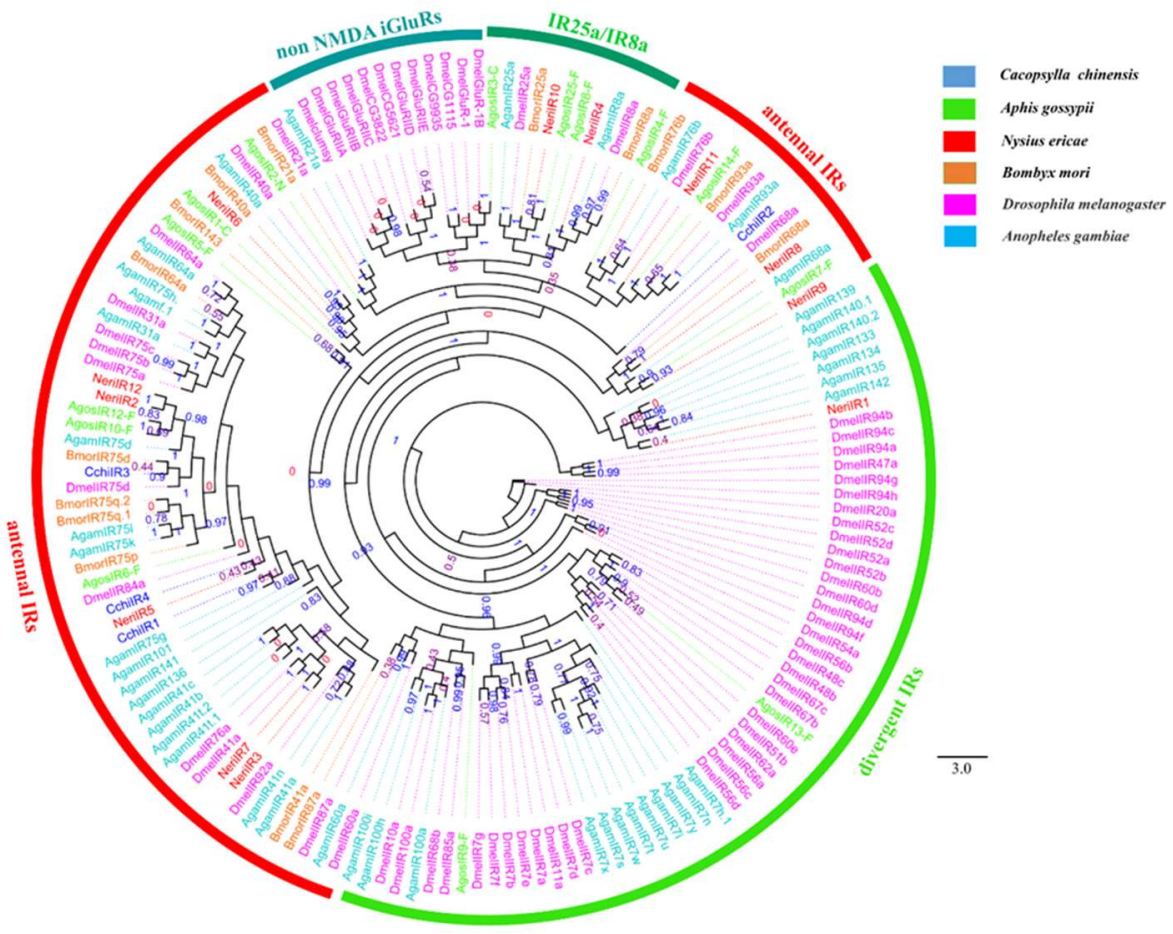

Figure 8. Phylogenetic tree of insect ionotropic receptors (IRs). The C. chinensis translated genes are shown in blue. Other insects are as follows: Aphis gossypii, Nysius ericae, Bombyx mori, Drosophila melanogaster, Anopheles gambiae. This tree was constructed using PhyML based on the alignment results of ClustalX2.0.

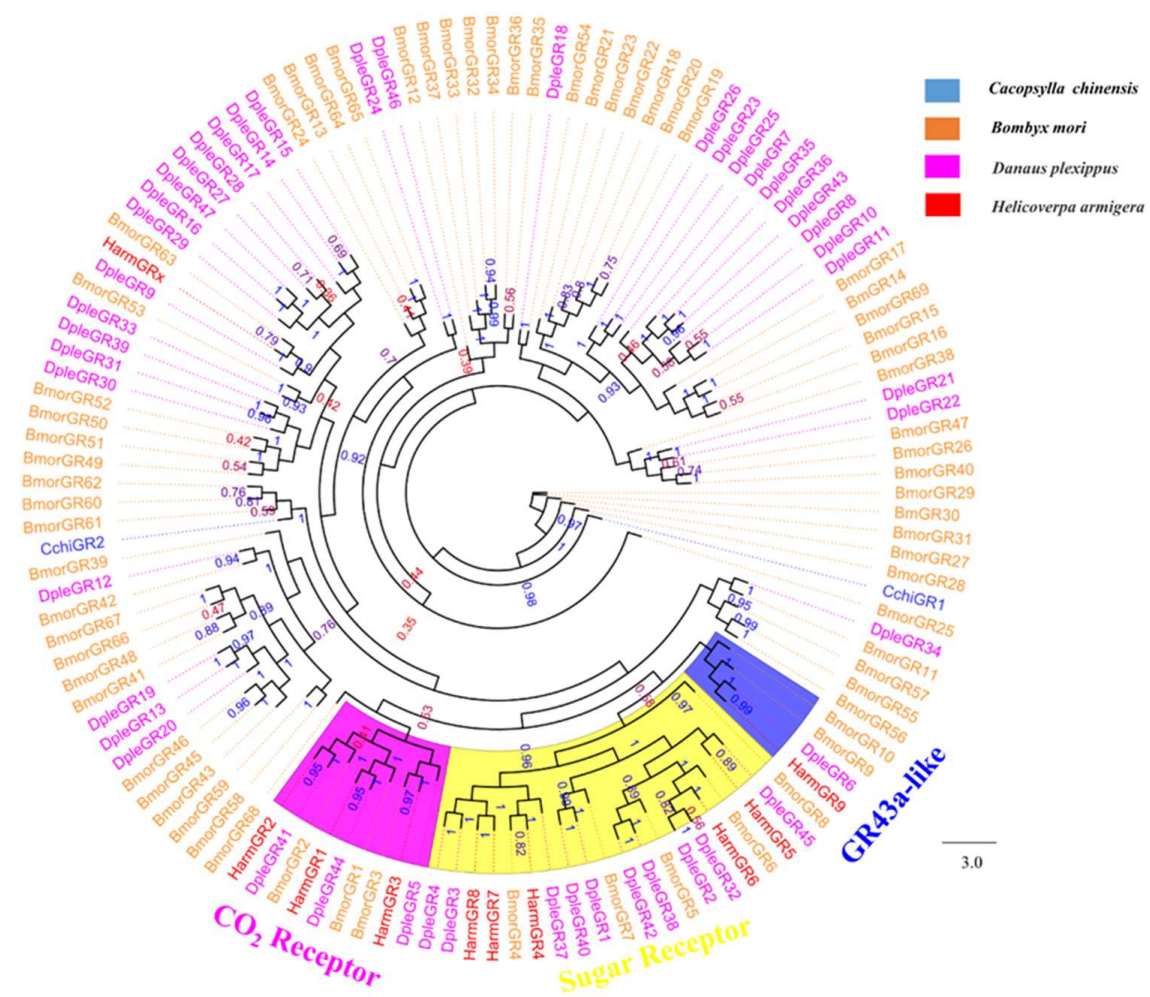

Figure 9. Phylogenetic tree of insect gustatory receptors (GRs). The C. chinensis translated genes are shown in blue. Other insects are as follows: Bombyx mori, Danaus plexippus, Helicoverpa armigera. This tree was constructed using PhyML based on the alignment results of ClustalX2.0. 

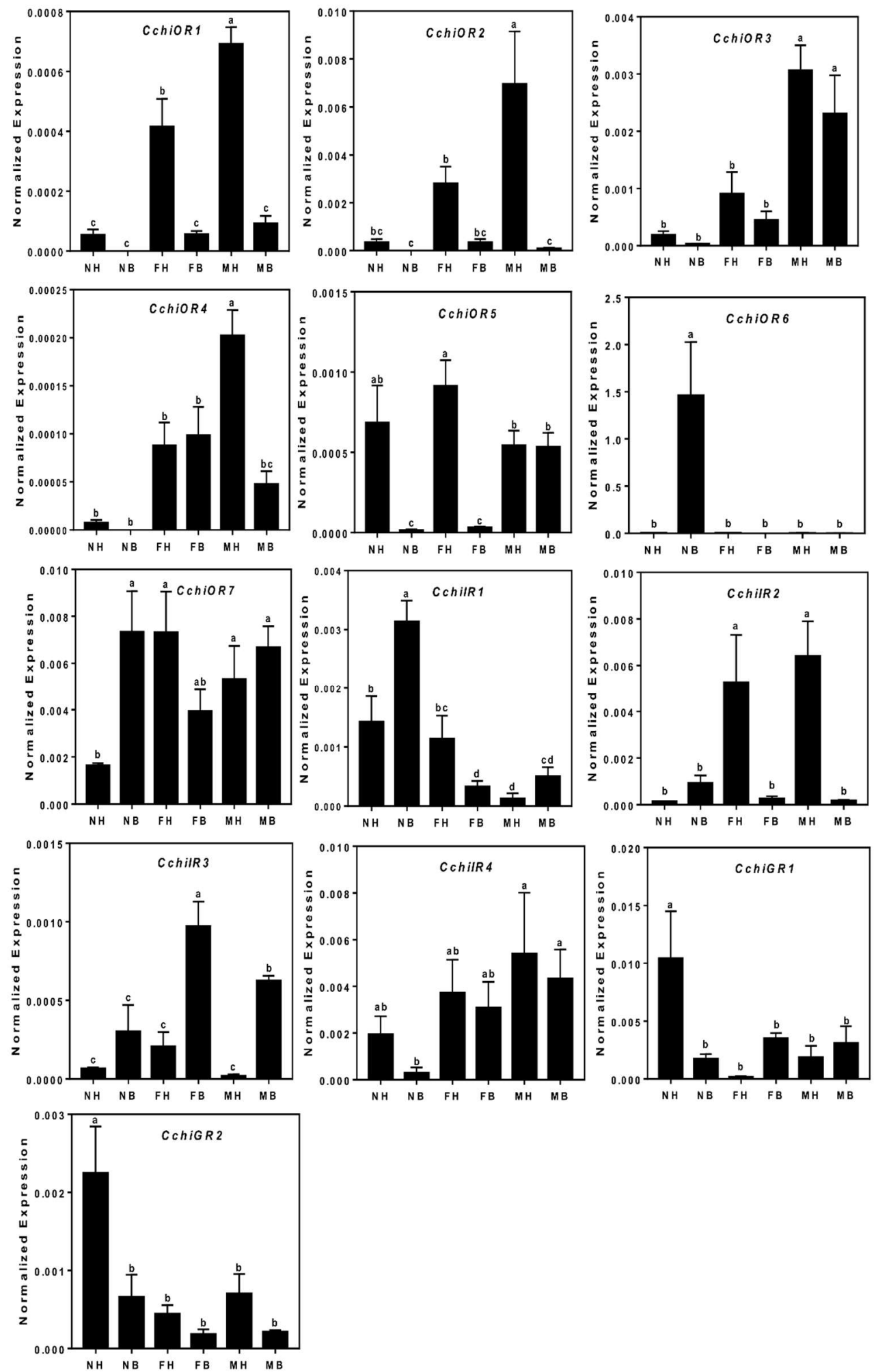

Figure 10. The tissue expression of chemosensory receptor genes in C. chinensis. The different lowercase letters mean significance between tissues ( $p<0.05$, ANOVA, LSD). NH, nymph head; NB, nymph body; $\mathrm{FH}$, female head; $\mathrm{FB}$, female body; $\mathrm{MH}$, male head; $\mathrm{MB}$, male body.

\section{Discussion}

As an important olfactory and taste organ, insect heads are important in communication and feeding behavior [61]. Therefore, the head has always been important in insect research, and a certain 
number of chemosensory genes have been found in the heads of different insects, such as S. furcifera [61], Tomicus yunnanensis [62], and Mythimna separate [63]. This suggests that chemosensory genes in insect heads should be associated with the above-mentioned chemosensory behaviors. In this study, we first sequenced and analyzed the head transcriptome of $C$. chinensis, and identified 36 chemosensory genes (12 OBPs, 11 CSPs, 7 ORs, 4 IRs, and 2 GRs), indicating C. chinensis can also regulate the corresponding behavioral response with the chemosensory genes of the head, just like the insects mentioned above. However, the number of chemosensory genes of $C$. chinensis is less than that of other Hemipteran insects, including 9 OBPs, 9 CSPs, 45 ORs, and 14 IRs of $A$. gossypii [64,65]; 9 OBPs, 12 CSPs, 46 ORs, 35 IRs, and 20 GRs of D. citri [66]; 12 OBPs, 9 CSPs, 63 ORs, and 14 IRs of S. furcifera [67,68]; and 11 OBPs, 17 CSPs, 50 ORs, and 10 GRs of Nilaparvata lugens $[69,70]$. This may reflect the fact that C. chinensis is an oligophagous insect and does not need as many chemosensory genes to recognize host volatiles.

The tissue expression results showed that all CchiOBPs were highly expressed in heads, indicating their involvement in the olfactory and gustatory processes of $C$. chinensis. Among the CchiOBPS, five CchiOBPs (CchiOBP1, 3-6) and two CchiOBPs (CchiOBP7, 11) were significantly highly expressed in the heads of females and males, respectively. Previous studies have revealed the different functions of OBPs in the chemosensory organs of insect heads. Female mosquitoes of Culex quinquefasciatus use CquiOBP1 to detect oviposition attractants [71,72], and male moths of Spodoptera litura recognize the female sex pheromones by pheromone binding proteins (SlitPBPs) [73], suggesting that insect OBPs participate in sex-related chemosensory behavior, and the seven CchiOBPs may have similar functions, i.e., regulating oviposition or mating behavior by detecting different pear volatiles or intraspecific pheromones. Additionally, two CchiOBPs (CchiOBP2 and 9) were significantly highly expressed in nymph heads. The highly expressed NlugOBP3 in nymphs of N. lugens is involved in nymph olfaction on rice seedlings as determined by integrating RNAi and ligand binding assays [74]. Thus, the two CchiOBPs may help C. chinensis to complete the feeding process on pear trees by detecting the pear volatiles. Interestingly, we found that CchiOBP8 was specifically expressed in both nymph heads and bodies, suggesting that it may take part in the feeding and/or other physiological processes of nymphs. The OBP phylogenetic tree showed that most CchiOBPs were adjacent in the phylogenetic tree to DcitOBPs of D. citri, indicating that the two species have high homology and some OBPs might have similar functions. The CchiOBP1 was clustered into the plus-C OBP subfamily, and others belonged to the classic subfamily, which is similar to D. citri and $S$. furcifera $[66,68]$, suggesting that the mechanism of functional differentiation of OBPs in Hemiptera insects may be the same.

Among all CchiCSPs, six CchiCSPs displayed head-biased expression, suggesting that these genes may have similar functions to the high expression of CchiOBPs in the head. The functions of CSPs expressed in important chemosensory organs of the head have been reported in different insects, such as SfurCSP5 of $S$. furcifera has high affinities for three rice volatiles (2-tridecanone, 2-pentadecanone, and $\beta$-ionone) [75], and three host volatiles [(Z)-3-hexen-1-ol, (E)-2-hexen-1-al, and valeraldehyde] have a high binding affinity with AlinCSPs (1, 2, and 3) of A. lineolatus [76], and SinfCSP19 of Sesamia inferens is able to bind sex pheromones and host plant volatiles [77]. These results suggest that this type of insect CSP may have similar functions as OBP in recognizing host volatiles and sex pheromones. In addition, many insect CSPs are broadly expressed in different tissues (leg, gut, and pheromone gland) [78-83] and have non-chemosensory functions; for example, SexiCSP3 is involved in survival and reproduction in S. exigua [84], AmelCSP5 is crucial in the formation of embryonic integument in Apis mellifera [85], and some midgut-expressed SlitCSPs of S. litura may have functional roles in the specialization and adaption to different ecosystems [82]. In our study, five of 11 CchiCSPs in C. chinensis were widely expressed in all investigated tissues, suggesting that these ChiCSPs may be involved in governing host plant choice and other physiological behaviors. According to our phylogenetic tree of CchiCSP genes, CSPs from C. chinensis and D. citri were grouped in the same clade, indicating that some CSP genes may have similar functions between the two species.

Chemosensory receptors stimulate corresponding physiological behavior of insects [86-88], and identification of chemosensory receptors is a key step in interpreting mechanisms of insect 
chemosensation. In this study, the OR phylogenetic trees showed that CchiOR2 belongs to the Orco family, which is necessary for locating other conventional ORs on dendritic membranes and for odor detection [89], and which indicates that $C$. chinensis shares chemosensory mechanisms with other insects $[90,91]$. Seven of 13 chemosensory receptor genes were highly expressed in the heads. Among them, two conventional CchiORs (CchiOR1 and 4) were more abundant in male heads than in other tissues, indicating that they may participate in recognizing odorants such as pheromones related to male physiological activities. This is similar to the pheromone receptor (PR) of moths, which specializes in the recognition of female sex pheromones [7,92,93]. Previous studies revealed a female-biased AlucOR46 of Apolygus lucorum tunes to some plant volatiles [(S)-(-)-limonene, (R)-(+)-limonene, (E)-2-hexenal, (E)-3-hexenol, 1-heptanol, and (1R)-(-)- myrtenol)] [94], three female-biased ORs of B. mori (OR19, 45 and 47) account for some of the female-specific odorant responses, such as oviposition cues (plant volatiles: linalool, benzoic acid, 2-phenylethanol and benzaldehyde) and/or detection of an as yet unidentified male-produced sex pheromone [95,96], and larvae-expressed BmorOR56 has high selective tuning to cis-jasmone, a key mulberry leaf volatile [97]. Thus, CchiOR5, which was highly expressed in both female and nymph heads, may have similar roles in C. chinensis. Mang found that larvae-expressed BmorGR9 is involved in the promotion of feeding behaviors [98], indicating that CchiGR1 and 2, which were highly expressed in nymph heads, may also participate in the feeding progress of $C$. chinensis. BmorGR6, which exists in different tissues (midgut, central nervous system, and oral sensory organs), is not only a taste receptor but also a chemical sensor for the regulation of gut movement, physiological conditions, and feeding behavior of B. mori larvae [99]. The highly expressed foregut-specific HarmGR9 of $H$. armigera may contribute to the regulation of larval feeding behavior [100], and some SlitIRs of $S$. litura were detected in proboscises, legs, abdomens, and reproductive tissues and may have diverse functional roles in olfaction, taste, and reproduction [101]. We also found widely-expressed genes such as CchiOR7 and CchilR4, in contrast to those highly or specifically expressed in female and/or nymph bodies (CchiIR3, CchiIR1, and CchiOR6), indicating these five chemosensory receptors may play a vital role in regulating feeding and other physiological behaviors. The exact function of these genes could be further analyzed by integrating in vivo and in vivo methods $[92,93,102]$.

\section{Conclusions}

In conclusion, we identified an extensive set of chemosensory genes that may be related to the chemosensory and gustatory behaviors of $C$. chinensis by sequencing and analyzing head transcriptomic data. As a first step towards understanding their functions, we comprehensively compared phylogeny and tissue expression and demonstrated male head, female head, and nymph-biased specific/expression genes. Our results provide a valuable resource for analyzing the function of key genes in developing effective biological control agents, as well as helping to describe the chemosensory system in $C$. chinensis and other oligophagous pests.

Supplementary Materials: The following are available online at http://www.mdpi.com/2075-4450/10/6/175/s1, Table S1: Amino acid sequences of $C$. chinensis and other insects used in phylogenetic analyses; Table S2: Primers used for qRT-PCR.

Author Contributions: Y.-N.Z. and X.-Y.Z. conceived and designed the experiments; J.-W.X., Q.-J.C., Y.-J.Z., Y.-X.Y., R.-R.W., Y.Z., M.-Z.X., Y.-T.G., and X.-L.W. performed the experiments; J.-W.X., F.Z., X.-Y.Z., L.J., L.X. and Y.-N.Z. analyzed the data; J.-W.X. and Y.-N.Z. wrote the paper.

Funding: This work was supported by the Natural Science Fund of Education Department of Anhui Province, China (Leading Researcher: X.-Y.Z., Title: Identification, Cloning and Expression Characterization of Chemosensory Genes in Cacopsylla chinensis); National College Students' Innovation and Entrepreneurship Training Program (201810373097); Anhui College Students' Innovation and Entrepreneurship Training Program (201810373097); Postgraduate Innovation Fund of Huaibei Normal University (ycx201901005); Provincial Natural Science Foundation of Anhui (1708085QC71); Key projects of Anhui Province University Outstanding Youth Talent Support Program (gxgwfx2019023 and gxgnfx2018010).

Acknowledgments: We thank students Wei-Chen Yao and Rui Zhu (Huaibei Normal University, China) for their help in collecting insects. 
Conflicts of Interest: The authors declare no conflict of interest.

\section{References}

1. Field, L.M.; Pickett, J.A.; Wadhams, L.J. Molecular studies in insect olfaction. Insect Mol. Biol. 2000, 9, 545-551. [CrossRef] [PubMed]

2. Leal, W.S. Odorant reception in insects: Roles of receptors, binding proteins, and degrading enzymes. Annu. Rev. Entomol. 2013, 58, 373-391. [CrossRef] [PubMed]

3. Fan, J.; Francis, F.; Liu, Y.; Chen, J.L.; Cheng, D.F. An overview of odorant-binding protein functions in insect peripheral olfactory reception. Genet. Mol. Res. 2011, 10, 3056. [CrossRef] [PubMed]

4. Montagné, N.; Fouchier, A.D.; Newcomb, R.D.; Jacquin-Joly, E. Advances in the Identification and Characterization of Olfactory Receptors in Insects. Prog. Mol. Biol. Transl. 2014, 130, 55-80. [CrossRef]

5. Paula, D.P.; Togawa, R.C.; Costa, M.M.; Grynberg, P.; Martins, N.F.; Andow, D.A. Identification and expression profile of odorant-binding proteins in Halyomorpha halys (Hemiptera: Pentatomidae). Insect Mol. Biol. 2016, 25, 580-594. [CrossRef]

6. Tunstall, N.E.; Warr, C.G. Chemical communication in insects: The peripheral odour coding system of Drosophila melanogaster. In Sensing in Nature; Springer: Berlin, Germany, 2012; pp. 59-77.

7. Zhang, J.; Walker, W.B.; Wang, G. Pheromone reception in moths: From molecules to behaviors. Prog. Mol. Biol. Transl. Sci. 2015, 130, 109-128. [CrossRef] [PubMed]

8. Pelosi, P.; Calvello, M.; Ban, L. Diversity of Odorant-binding Proteins and Chemosensory Proteins in Insects. Chem. Senses 2005, 30 (Suppl. 1), i291-i292. [CrossRef]

9. Xu, Y.-L.; He, P.; Zhang, L.; Fang, S.-Q.; Dong, S.-L.; Zhang, Y.-J.; Li, F. Large-scale identification of odorant-binding proteins and chemosensory proteins from expressed sequence tags in insects. BMC. Genom. 2009, 10, 632. [CrossRef]

10. Mckenna, M.P.; Hekmat-Scafe, D.S.; Gaines, P.; Carlson, J.R. Putative Drosophila pheromone-binding proteins expressed in a subregion of the olfactory system. J. Biol. Chem. 1994, 269, 16340-16347. [CrossRef]

11. Vogt, R.G.; Riddiford, L.M. Pheromone binding and inactivation by moth antennae. Nature 1981, 293, 161-163. [CrossRef]

12. Vogt, R.G. Biochemical diversity of odor detection: OBPs, ODEs and SNMPs. In Insect Pheromone Biochemistry and Molecular Biology; Blomquist, G., Vogt, R., Eds.; Academic Press: San Diego, CA, USA, 2003; pp. 391-445.

13. Sanchez-Gracia, A.; Vieira, F.G.; Rozas, J. Molecular evolution of the major chemosensory gene families in insects. Heredity 2009, 103, 208-216. [CrossRef] [PubMed]

14. Maleszka, J.; Forêt, S.; Saint, R.; Maleszka, R. RNAi-induced phenotypes suggest a novel role for a chemosensory protein CSP5 in the development of embryonic integument in the honeybee (Apis mellifera). Dev. Genes Evol. 2007, 217, 189-196. [CrossRef] [PubMed]

15. Christensen, T.A.; Hildebrand, J.G. Pheromonal and host-odor processing in the insect antennal lobe: How different? Curr. Opin. Neurobiol. 2002, 12, 393-399. [CrossRef]

16. Cunningham, J.P.; Moore, C.J.; Zalucki, M.P.; Cribb, B.W. Insect odour perception: Recognition of odour components by flower foraging moths. Proc. R. Soc. B Biol. Sci. 2006, 273, 2035-2040. [CrossRef] [PubMed]

17. Carey, A.F.; Wang, G.; Su, C.Y.; Zwiebel, L.J.; Carlson, J.R. Odorant reception in the malaria mosquito Anopheles gambiae. Nature 2010, 464, 66-71. [CrossRef] [PubMed]

18. Hopf, T.A.; Morinaga, S.; Ihara, S.; Touhara, K.; Marks, D.S.; Benton, R. Amino acid coevolution reveals three-dimensional structure and functional domains of insect odorant receptors. Nat. Commun. 2015, 6, 6077. [CrossRef] [PubMed]

19. Smith, D.P. Odor and pheromone detection in Drosophila melanogaster. Pflïg. Arch. Eur. J. Physiol. 2007, 454, 749-758. [CrossRef] [PubMed]

20. Pitts, R.J.; Fox, A.N.; Zwiebel, L.J. A highly conserved candidate chemoreceptor expressed in both olfactory and gustatory tissues in the malaria vector Anopheles gambiae. Proc. Natl. Acad. Sci. USA 2004, 101, 5058-5063. [CrossRef]

21. Haverkamp, A.; Hansson, B.S.; Knaden, M. Combinatorial codes and labeled lines: How insects use olfactory cues to find and judge food, mates, and oviposition sites in complex environments. Front. Physiol. 2018, 9, 49. [CrossRef] 
22. Knaden, M.; Strutz, A.; Ahsan, J.; Sachse, S.; Hansson, B.S. Spatial representation of odorant valence in an insect brain. Cell Rep. 2012, 1, 392-399. [CrossRef]

23. Dweck, H.M.; Ebrahim, S.M.; Kromann, S.; Bown, D.; Hillbur, Y.; Sachse, S.; Hansson, B.; Stensmyr, M. Olfactory preference for egg laying on citrus substrates in Drosophila. Curr. Biol. 2013, 23, 2472-2480. [CrossRef] [PubMed]

24. Wang, T.T.; Si, F.L.; He, Z.B.; Chen, B. Genome-wide identification, characterization and classification of ionotropic glutamate receptor genes (iGluRs) in the malaria vector Anopheles sinensis (Diptera: Culicidae). Parasites Vectors 2018, 11, 34. [CrossRef] [PubMed]

25. Benton, R.; Vannice, K.S.; Gomez-Diaz, C.; Vosshall, L.B. Variant ionotropic glutamate receptors as chemosensory receptors in Drosophila. Cell 2009, 136, 149-162. [CrossRef] [PubMed]

26. Abuin, L.; Bargeton, B.; Ulbrich, M.H.; Isacoff, E.Y.; Kellenberger, S.; Benton, R. Functional architecture of olfactory ionotropic glutamate receptors. Neuron 2011, 69, 44-60. [CrossRef] [PubMed]

27. Liu, N.Y.; Xu, W.; Dong, S.L.; Zhu, J.Y.; Xu, Y.X.; Anderson, A. Genome-wide analysis of ionotropic receptor gene repertoire in Lepidoptera with an emphasis on its functions of Helicoverpa armigera. Insect Biochem. Mol. Biol. 2018, 99, 37-53. [CrossRef]

28. Enjin, A.; Zaharieva, E.E.; Frank, D.D.; Mansourian, S.; Suh, G.S.; Gallio, M.; Stensmyr, M.C. Humidity Sensing in Drosophila. Curr. Biol. 2016, 26, 1352-1358. [CrossRef]

29. Chen, C.; Buhl, E.; Xu, M.; Croset, V.; Rees, J.S.; Lilley, K.S.; Benton, R.; Hodge, J.J.; Stanewsky, R.J.N. Drosophila Ionotropic Receptor 25a mediates circadian clock resetting by temperature. Nature 2015, 527, 516. [CrossRef]

30. Liman, E.; Zhang, Y.; Montell, C. Peripheral coding of taste. Neuron 2014, 81, 984-1000. [CrossRef]

31. Robertson, H.M. Molecular evolution of the major arthropod chemoreceptor gene families. Annu. Rev. Entomol. 2019, 64, 227-242. [CrossRef]

32. Pentzold, S.; Burse, A.; Boland, W. Contact chemosensation of phytochemicals by insect herbivores. Nat. Prod. Rep. 2017, 34, 478-483. [CrossRef]

33. Wright, G.A. To feed or not to feed: Circuits involved in the control of feeding in insects. Curr. Opin. Neurobiol. 2016, 41, 87-91. [CrossRef]

34. Cui, H.H.; Gu, S.H.; Zhu, X.Q.; Wei, Y.; Liu, H.W.; Khalid, H.D.; Guo, Y.Y.; Zhang, Y.J. Odorant-binding and chemosensory proteins identified in the antennal transcriptome of Adelphocoris suturalis Jakovlev. Comp. Biochem. Physiol. 2017, 24, 139-145. [CrossRef] [PubMed]

35. Bin, S.Y.; Qu, M.Q.; Pu, X.H.; Wu, Z.Z.; Lin, J.T. Antennal transcriptome and expression analyses of olfactory genes in the sweetpotato weevil Cylas formicarius. Sci. Rep. 2017, 7, 11073. [CrossRef] [PubMed]

36. Wang, H.L.; Yang, J.; Boykin, L.M.; Zhao, Q.Y.; Li, Q.; Wang, X.W.; Liu, S.S. The characteristics and expression profiles of the mitochondrial genome for the Mediterranean species of the Bemisia tabaci complex. BMC. Genom. 2013, 14, 401. [CrossRef] [PubMed]

37. Hekmat-Scafe, D.S.; Scafe, C.R.; Mckinney, A.J.; Tanouye, M.A. Genome-wide analysis of the odorant-binding protein gene family in Drosophila melanogaster. Genome Res. 2002, 12, 1357-1369. [CrossRef] [PubMed]

38. Yang, C.; Li, F. The Pear psylla (Homoptera) of China with descriptions of seven new species. Entomotaxonomia 1981, 3, 35-47.

39. Sun, J.R.; Yan, L.I.; Yan, S.; Zhang, Q.W.; Xu, H.L. Microsatellite marker analysis of genetic diversity of Cacopsylla chinensis (Yang et Li) (Hemiptera: Psyllidae) populations in China. Acta Entomol. Sin. 2011, 54, 820-827. [CrossRef]

40. Blomquist, C.L.; Kirkpatrick, B.C. Frequency and Seasonal Distribution of Pear Psylla Infected with the Pear Decline Phytoplasma in California Pear Orchards. Plant. Pathol. 2002, 92, 1218-1226. [CrossRef] [PubMed]

41. Kang, A.R.; Baek, J.Y.; Lee, S.H.; Cho, Y.S.; Kim, W.S.; Han, Y.S.; Kim, I. Geographic homogeneity and high gene flow of the pear psylla, Cacopsylla pyricola (Hemiptera: Psyllidae), detected by mitochondrial COI gene and nuclear ribosomal internal transcribed spacer 2. Anim. Cells Syst. 2012, 16, 145-153. [CrossRef]

42. Yang, C.L.; Zhu, H.Y.; Zhang, F. Comparative proteomics analysis between the short-term stress and long-term adaptation of the Blattella germanica (Blattodea: Blattellidae) in response to beta-cypermethrin. J. Econ. Entomol. 2019. [CrossRef]

43. Zhang, X.C.; Zhang, F. The potential control strategies based on the interaction between indoor cockroaches and their symbionts in China. Adv. Insect. Physiol. 2018, 55, 55-122. 
44. Guo, S.J.; Yan, X.Y.; Shi, F.F.; Ma, K.; Chen, Z.J.; Zhang, C. Expression and distribution of the zinc finger protein, SNAI3, in mouse ovaries and pre-implantation embryos. J. Reprod. Dev. 2018, 64, 179-186. [CrossRef] [PubMed]

45. Li, H.; Li, T.; Guo, Y.J.; Li, Y.J.; Zhang, Y.; Teng, N.; Zhang, F.M.; Yang, G.W. Molecular characterization and expression patterns of a non-mammalian toll-like receptor gene (TLR21) in larvae ontogeny of common carp (Cyprinus carpio L.) and upon immune stimulation. BMC. Vet. Res 2018, 14. [CrossRef] [PubMed]

46. Zhang, F.; Wang, X.J.; Huang, Y.H.; Zhao, Z.G.; Zhang, S.S.; Gong, X.S.; Xie, L.; Kang, D.M.; Jing, X. Differential expression of hemolymph proteins between susceptible and insecticide-resistant Blattella germanica (Blattodea: Blattellidae). Environ. Entomol. 2014, 43, 1117-1123. [CrossRef] [PubMed]

47. Haas, B.J.; Papanicolaou, A.; Yassour, M.; Grabherr, M.G.; Blood, P.D.; Bowden, J.; Couger, M.B.; Eccles, D.; Li, B.; Lieber, M. De novo transcript sequence reconstruction from RNA-seq using the Trinity platform for reference generation and analysis. Nat. Protoc. 2013, 8, 1494-1512. [CrossRef] [PubMed]

48. Deng, Y.Y.; Li, J.Q.; Wu, S.F. Integrated $\mathrm{nr}$ database in protein annotation system and its localization. Comput. Eng. 2006, 32, 71-74.

49. Apweiler, R.; Bairoch, A.; Wu, C.H.; Barker, W.C.; Boeckmann, B.; Ferro, S.; Gasteiger, E.; Huang, H.; Lopez, R.; Magrane, M. UniProt: The universal protein knowledgebase. Nucleic Acids Res. 2004, 32, D115-D119. [CrossRef]

50. Kanehisa, M.; Goto, S.; Kawashima, S.; Okuno, Y.; Hattori, M. The KEGG resource for deciphering the genome. Nucleic. Acids. Res. 2004, 32, D277-D280. [CrossRef]

51. Jensen, L.J.; Julien, P.; Kuhn, M.; Mering, C.; Muller, J.; Doerks, T.; Bork, P. eggNOG: Automated construction and annotation of orthologous groups of genes. Nucleic Acids Res. 2008, 36, D250-D254. [CrossRef]

52. Tatusov, R.L.; Galperin, M.Y.; Natale, D.A.; Koonin, E.V. The COG database: A tool for genome-scale analysis of protein functions and evolution. Nucleic. Acids. Res. 2000, 28, 33-36. [CrossRef]

53. Zhang, Z.; Wood, W. A profile hidden Markov model for signal peptides generated by HMMER. Bioinformatics 2003, 19, 307-308. [CrossRef] [PubMed]

54. Bateman, A.; Coin, L.; Durbin, R.; Finn, R.; Hollich, V.; Griffiths-Jones, S.; Khanna, A.; Marshall, M.; Moxon, S.; Sonnhammer, E. The Pfam protein families database. Nucleic. Acids. Res. 2004, 32, D138-D141. [CrossRef] [PubMed]

55. Nielsen, H. Predicting Secretory Proteins with SignalP. Methods. Mol. Biol. 2017, 1611, 59-73. [PubMed]

56. Guindon, S.; Dufayard, J.F.; Lefort, V.; Anisimova, M.; Hordijk, W.; Gascuel, O. New algorithms and methods to estimate maximum-likelihood phylogenies: Assessing the performance of PhyML 3.0. Syst. Biol. 2010, 59, 307-321. [CrossRef] [PubMed]

57. Le, S.Q.; Gascuel, O. An improved general amino acid replacement matrix. Mol. Biol. Evol. 2008, 25, 1307-1320. [CrossRef] [PubMed]

58. Bustin, S.A.; Benes, V.; Garson, J.A.; Hellemans, J.; Huggett, J.; Kubista, M.; Mueller, R.; Nolan, T.; Pfaffl, M.W.; Shipley, G.L.; et al. The MIQE guidelines: Minimum information for publication of quantitative real-time PCR experiments. Clin. Chem. 2009, 55, 611-622. [CrossRef] [PubMed]

59. Muller, P.Y.; Janovjak, H.; Miserez, A.Z. Processing of gene expression data generated by quantitative real-time RT-PCR. Biotechniques 2002, 32, 1372-1374. [CrossRef]

60. Hou, P.L.; Zhao, G.M.; He, C.Q.; Wang, H.M.; He, H.B. Biopanning of polypeptides binding to bovine ephemeral fever virus G(1) protein from phage display peptide library. BMC. Vet. Res. 2018, 14, 9. [CrossRef]

61. He, M.; Zhang, Y.N.; He, P. Molecular characterization and differential expression of an olfactory receptor gene family in the white-backed planthopper Sogatella furcifera based on transcriptome analysis. PLoS ONE 2015, 10, e0140605. [CrossRef]

62. Zhu, J.Y.; Zhao, N.; Yang, B. Global transcriptional analysis of olfactory genes in the head of pine shoot beetle, Tomicus yunnanensis. Comp. Funct. Genom. 2012, 2012. [CrossRef]

63. Liu, Z.; Wang, X.; Lei, C.; Zhu, F. Sensory genes identification with head transcriptome of the migratory armyworm, Mythimna separata. Sci. Rep. 2017, 7, 46033. [CrossRef] [PubMed]

64. Cao, D.; Liu, Y.; Walker, W.B.; Li, J.; Wang, G. Molecular characterization of the Aphis gossypii olfactory receptor gene families. PLoS ONE 2014, 9, e101187. [CrossRef] [PubMed]

65. Gu, S.H.; Wu, K.M.; Guo, Y.Y.; Field, L.M.; Pickett, J.A.; Zhang, Y.J.; Zhou, J.J. Identification and expression profiling of odorant binding proteins and chemosensory proteins between two wingless morphs and a winged morph of the cotton aphid Aphis gossypii Glover. PLoS ONE 2013, 8, e73524. [CrossRef] [PubMed] 
66. Wu, Z.; Zhang, H.; Bin, S.; Chen, L.; Han, Q.; Lin, J. Antennal and Abdominal Transcriptomes Reveal Chemosensory Genes in the Asian Citrus Psyllid, Diaphorina citri. PLoS ONE 2016, 11, e0159372. [CrossRef] [PubMed]

67. Zhou, W.; Yuan, X.; Qian, P.; Cheng, J.; Zhang, C.; Gurr, G.; Zhu, Z.R. Identification and expression profiling of putative chemosensory protein genes in two rice planthoppers, Laodelphax striatellus (Fallén) and Sogatella furcifera (Horváth). J. Asia-Pac. Entomol. 2015, 18, 771-778. [CrossRef]

68. He, M.; He, P. Molecular characterization, expression profiling, and binding properties of odorant binding protein genes in the whitebacked planthopper, Sogatella furcifera. Comp. Biochem. Physiol. B Biochem. Mol. Biol. 2014, 174, 1-8. [CrossRef] [PubMed]

69. Zhou, S.S.; Sun, Z.; Ma, W.; Chen, W.; Wang, M.Q. De novo analysis of the Nilaparvata lugens (Stål) antenna transcriptome and expression patterns of olfactory genes. Comp. Biochem. Physiol. D Genomics Proteomics 2014, 9, 31-39. [CrossRef] [PubMed]

70. Yang, K.; He, P.; Dong, S.L. Different expression profiles suggest functional differentiation among chemosensory proteins in Nilaparvata lugens (Hemiptera: Delphacidae). J. Insect Sci. 2014, 14, 270. [CrossRef]

71. Mao, Y.; Xu, X.; Xu, W.; Ishida, Y.; Leal, W.S.; Ames, J.B.; Clardy, J. Crystal and solution structures of an odorant-binding protein from the southern house mosquito complexed with an oviposition pheromone. Proc. Natl. Acad. Sci. USA 2010, 107, 19102-19107. [CrossRef]

72. Pelletier, J.; Guidolin, A.; Syed, Z.; Cornel, A.J.; Leal, W.S. Knockdown of a mosquito odorant-binding protein involved in the sensitive detection of oviposition attractants. J. Chem. Ecol. 2010, 36, 245-248. [CrossRef]

73. Liu, N.Y.; Liu, C.C.; Dong, S.L. Functional differentiation of pheromone-binding proteins in the common cutworm Spodoptera litura. Comp. Biochem. Physiol. A Mol. Integr. Physiol. 2013, 165, 254-262. [CrossRef] [PubMed]

74. He, P.; Zhang, J.; Liu, N.Y.; Zhang, Y.N.; Yang, K.; Dong, S.L. Distinct expression profiles and different functions of odorant binding proteins in Nilaparvata lugens Stål. PLoS ONE 2011, 6, e28921. [CrossRef] [PubMed]

75. Chen, G.L.; Pan, Y.F.; Ma, Y.F.; Wang, J.; He, M.; He, P. Binding affinity characterization of an antennae-enriched chemosensory protein from the white-backed planthopper, Sogatella furcifera (Horvath), with host plant volatiles. Pestic. Biochem. Physiol. 2018, 152, 1-7. [CrossRef] [PubMed]

76. Gu, S.H.; Wang, S.Y.; Zhang, X.Y.; Ji, P.; Liu, J.T.; Wang, G.R.; Wu, K.M.; Guo, Y.Y.; Zhou, J.J.; Zhang, Y.J. Functional characterizations of chemosensory proteins of the Alfalfa Plant Bug Adelphocoris lineolatus indicate their involvement in host recognition. PLoS ONE 2012, 7, e42871. [CrossRef] [PubMed]

77. Zhang, Y.N.; Ye, Z.F.; Yang, K.; Dong, S.L. Antenna-predominant and male-biased CSP19 of Sesamia inferens is able to bind the female sex pheromones and host plant volatiles. Gene 2014, 536, 279-286. [CrossRef] [PubMed]

78. Calvello, M.; Brandazza, A.; Navarrini, A.; Dani, F.R.; Turillazzi, S.; Felicioli, A.; Pelosi, P. Expression of odorant-binding proteins and chemosensory proteins in some Hymenoptera. Insect Biochem. Mol. Biol. 2005, 35, 297-307. [CrossRef] [PubMed]

79. Zhou, J.J.; Kan, Y.; Antoniw, J.; Pickett, J.A.; Field, L.M. Genome and eST analyses and expression of a gene family with putative functions in insect chemoreception. Chem. Senses 2006, 31, 453. [CrossRef] [PubMed]

80. Zhang, Y.-N.; Jin, J.-Y.; Jin, R.; Xia, Y.-H.; Zhou, J.-J.; Deng, J.-Y.; Dong, S.-L. Differential expression patterns in chemosensory and non-chemosensory tissues of putative chemosensory genes identified by transcriptome analysis of insect pest the purple stem borer Sesamia inferens (Walker). PLoS ONE 2013, 8, e69715. [CrossRef]

81. Qiao, H.L.; Deng, P.Y.; Li, D.D.; Chen, M.; Jiao, Z.J.; Liu, Z.C.; Zhang, Y.Z.; Kan, Y.C. Expression analysis and binding experiments of chemosensory proteins indicate multiple roles in Bombyx mori. J. Insect Physiol. 2013, 59, 667-675. [CrossRef]

82. Yi, X.; Qi, J.; Zhou, X.; Hu, M.Y.; Zhong, G.H. Differential expression of chemosensory-protein genes in midguts in response to diet of Spodoptera litura. Sci. Rep. 2017, 7, 296. [CrossRef] [PubMed]

83. Zhang, Y.N.; Zhu, X.Y.; Fang, L.P.; He, P.; Wang, Z.Q.; Chen, G.; Sun, L.; Ye, Z.F.; Deng, D.G.; Li, J.B. Identification and expression profiles of sex pheromone biosynthesis and transport related genes in Spodoptera litura. PLoS ONE 2015, 10, e0140019. [CrossRef] [PubMed]

84. Gong, L.; Luo, Q.; Rizwan-Ul-Haq, M.; Hu, M.Y. Cloning and characterization of three chemosensory proteins from Spodoptera exigua and effects of gene silencing on female survival and reproduction. Bull. Entomol. Res. 2012, 102, 600-609. [CrossRef] [PubMed] 
85. Foret, S.; Wanner, K.W.; Maleszka, R. Chemosensory proteins in the honey bee: Insights from the annotated genome, comparative analyses and expressional profiling. Insect Biochem. Mol. Biol. 2007, 37, 19-28. [CrossRef] [PubMed]

86. Crasto, C.J. Olfactory Receptors. In Methods in Molecular Biology; Walker, J.M., Ed.; Humana Press: New York, NY, USA, 2013; Volume 2013. [CrossRef]

87. Rytz, R.; Croset, V.; Benton, R. Ionotropic receptors (IRs): Chemosensory ionotropic glutamate receptors in Drosophila and beyond. Insect Biochem. Mol. Biol. 2013, 43, 888-897. [CrossRef] [PubMed]

88. Agnihotri, A.R.; Roy, A.A.; Joshi, R.S. Gustatory receptors in Lepidoptera: Chemosensation and beyond. Insect Mol. Biol. 2016, 25, 519-529. [CrossRef] [PubMed]

89. Stengl, M.; Funk, N.W. The role of the coreceptor Orco in insect olfactory transduction. J. Comp. Physiol. A 2013, 199, 897-909. [CrossRef] [PubMed]

90. Butterwick, J.A.; Del Marmol, J.; Kim, K.H.; Kahlson, M.A.; Rogow, J.A.; Walz, T.; Ruta, V. Cryo-EM structure of the insect olfactory receptor Orco. Nature 2018, 560, 447-452. [CrossRef] [PubMed]

91. DeGennaro, M.; McBride, C.S.; Seeholzer, L.; Nakagawa, T.; Dennis, E.J.; Goldman, C.; Jasinskiene, N.; James, A.A.; Vosshall, L.B. orco mutant mosquitoes lose strong preference for humans and are not repelled by volatile DEET. Nature 2013, 498, 487-491. [CrossRef]

92. Chang, H.; Liu, Y.; Ai, D.; Jiang, X.; Dong, S.; Wang, G. A Pheromone antagonist regulates optimal mating time in the moth Helicoverpa armigera. Curr. Biol. 2017, 27, 1610-1615. [CrossRef]

93. Zhang, Y.N.; Du, L.X.; Xu, J.W.; Wang, B.; Zhang, X.Q.; Yan, Q.; Wang, G. Functional characterization of four sex pheromone receptors in the newly discovered maize pest Athetis lepigone. J. Insect Physiol. 2019, 113, 59-66. [CrossRef]

94. Zhang, Z.; Zhang, M.; Yan, S.; Wang, G.; Liu, Y. A female-biased odorant receptor from Apolygus lucorum (Meyer-Dur) tuned to some plant odors. Int. J. Mol. Sci. 2016, 17, 1165. [CrossRef] [PubMed]

95. Anderson, A.R.; Wanner, K.W.; Trowell, S.C.; Warr, C.G.; Jaquin-Joly, E.; Zagatti, P.; Robertson, H.; Newcomb, R.D. Molecular basis of female-specific odorant responses in Bombyx mori. Insect Biochem. Mol. Biol. 2009, 39, 189-197. [CrossRef]

96. Widmayer, P.; Heifetz, Y.; Breer, H. Expression of a pheromone receptor in ovipositor sensilla of the female moth (Heliothis virescens). Insect Mol. Biol. 2009, 18, 541-547. [CrossRef] [PubMed]

97. Tanaka, K.; Uda, Y.; Ono, Y.; Nakagawa, T.; Suwa, M.; Yamaoka, R.; Touhara, K. Highly selective tuning of a silkworm olfactory receptor to a key mulberry leaf volatile. Curr. Biol. 2009, 19, 881-890. [CrossRef] [PubMed]

98. Mang, D.; Shu, M.; Tanaka, S.; Nagata, S.; Takada, T.; Endo, H.; Kikuta, S.; Tabunoki, H.; Iwabuchi, K.; Sato, R. Expression of the fructose receptor BmGr9 and its involvement in the promotion of feeding, suggested by its co-expression with neuropeptide F1 in Bombyx mori. Insect Biochem. Mol. Biol. 2016, 75, 58-69. [CrossRef] [PubMed]

99. Mang, D.; Shu, M.; Endo, H.; Yoshizawa, Y.; Nagata, S.; Kikuta, S.; Sato, R. Expression of a sugar clade gustatory receptor, BmGr6, in the oral sensory organs, midgut, and central nervous system of larvae of the silkworm Bombyx mori. Insect Biochem. Mol. Biol. 2016, 70, 85-98. [CrossRef] [PubMed]

100. Xu, W.; Zhang, H.J.; Anderson, A. A sugar gustatory receptor identified from the foregut of cotton bollworm Helicoverpa armigera. J. Chem. Ecol. 2012, 38, 1513-1520. [CrossRef]

101. Zhu, J.Y.; Xu, Z.W.; Zhang, X.M.; Liu, N.Y. Genome-based identification and analysis of ionotropic receptors in Spodoptera litura. Naturwissenschaften 2018, 105, 38. [CrossRef]

102. Jiang, X.J.; Ning, C.; Guo, H.; Jia, Y.Y.; Huang, L.Q.; Qu, M.J.; Wang, C.Z. A gustatory receptor tuned to d-fructose in antennal sensilla chaetica of Helicovera armigera. Insect Biochem. Mol. Biol. 2015, 60, $39-46$. [CrossRef]

(C) 2019 by the authors. Licensee MDPI, Basel, Switzerland. This article is an open access article distributed under the terms and conditions of the Creative Commons Attribution (CC BY) license (http://creativecommons.org/licenses/by/4.0/). 